\title{
BAROKOVÁ DUCHOVNÁ PIESEŇ AKO ŽIVÝ ODKAZ CYRILO-METODSKÉHO DEDIČSTVA ${ }^{1}$
}

\author{
Religious Songs of the Baroque Period as a Living Message \\ of the Cyrillo-Methodian Heritage
}

\author{
Silvia Lauková - Petra Kaizerová
}

DOI: 10.17846/CL.2020.13.2.137-152

\begin{abstract}
LAUKOVÁ, Silvia - KAIZEROVÁ, Petra. Religious Songs of the Baroque Period as a Living Message of the Cyrillo-Methodian Heritage. Cantus Catholici (1655) was the first printed Slovak Catholic hymn book. In the foreword, its compiler, the Jesuit Benedikt Szöllösi, refers to the Cyrillo-Methodian mission which proves the mission's importance for the development of Slovak national identity. Even in the Baroque period, the authorization of the use of the Slavonic liturgy by Pope Adrian II was an accepted argument to support the creation of a "folk" hymn book. Ancient ancestry of religious songs, their popularity among people and their use in non-sacral space were emphasized.

The compiler of the hymn book Cantus Catholici approached the selection and modification of songs in a specific way. The fact that the hymn book was addressed to the folk influenced the process of selecting songs which were well-known and popular (Christmas songs, Easter songs, songs for Lent, etc.). The songs had to be faithful to the creed and authentic in terms of their historicity and popularity among people on the territory of modern Slovakia. In his foreword, Benedikt Szöllösi highlights the idea of shared Slavic integrity and unity, and considering territorial and historical criteria, his selection gives strong preference to the Czech context. One of the sources of inspiration for Szöllösi's work was an older hymn book Písně katolické [Catholic songs] (1622) compiled by Jiř́ík Hlohovský and published in Olomouc. Studied hymn books - Slovak Cantus Catholici and Czech Písně katolické [Catholic songs] - come from different national and cultural milieus, yet, they both have shaped and added to the richness of European baroque cantional heritage. Their comparison shows that the Czech hymn book Písně katolické [Catholic songs] by Hlohovský was one of the main sources for the Slovak hymn book, although their interconnectedness was creative and original.
\end{abstract}

Keywords: Cyrillo-Methodian tradition, hymn book, song, acceptance, interconnectedness, Catholicism, Protestantism

Cyrilo-metodská misia sa v slovenskej histórii často nanovo zvýznamňovala. Predstavuje fenomén, ktorým sa argumentovalo v snahe legitimizovat mnohé politické a kultúrne snahy. Je podnetné sledovat ako s týmto odkazom pracujú jednotliví autori.

Vývin literatúry v barokovom období charakterizujú mnohé zákutia a dosial’ neprebádané oblasti. Jeho celkovú podobu môžeme iba tušit, skutočnú tvár iba hladat’ v ludských

Príspevok je výstupom v rámci projektu VEGA 1/0514/19 Poetika mystickej skúsenosti a literárne podoby mystagógie. 
dejinách - známych, pozabudnutých, zabudnutých alebo úplne stratených. Takýto stav výskumu literárneho baroka však súvisí nielen s jeho historickou povahou a časovou vzdialenostou od súčasnosti, ale aj so stavom našej literárnej historiografie - tá je síce erudovaná, ale tímy vedcov a bádatel’ov, ktorých úsilie podáva obraz o literárnej, komunikačnej a tvorivej situácii na území Slovenska v 17. a 18. storočí, nie sú dostatočne personálne obsadené.

Obdobie 17. a 18. storočia, v rozmedzí ktorého sa oficiálne datuje na území dnešného Slovenska barok, je obdobím mnohých zmien - spoločenských, ekonomických, sociálnych, ale aj estetických a mravných. Tvár baroka ovplyvňovali turecké vpády a nájazdy, stavovské a protihabsburské povstania, prírodné katastrofy, reformácia i rekatolizácia. Všetky tieto činitele mali za následok kolízny stav v krajine a pocit beznádeje jej obyvatelov. V prácach niektorých literárnych historiografov, predovšetkým predstavitel’ov staršej generácie, sa stretávame s názormi, že obdobie baroka môžeme najlepšie charakterizovat ako obdobie protireformácie, ako obdobie náboženskej neznášanlivosti (Vlček 1890, 2).

V súčasnosti je zjavné, že nielen reformácia, ale aj rekatolizácia sa závažným spôsobom zapísala do kultúrneho a spoločenského diania na území Slovenska. Slovenskí evanjelici i českí exulanti sa zapájali do kultúrneho a literárneho života v hojnejšej miere, tlaky na rekatolizáciu priniesli obrodu vkatolíckej cirkvi a zvýšený záujem o lud a jeho potreby, čo povzbudili aj závery Tridentského koncilu (1545 - 1563). Svoju činnost' rozvíjali rehole františkánov, piaristov a jezuitov, ktorí však svojou činnostou v prospech katolíckej cirkvi neraz vzbudzovali nenávist’ a neporozumenie. Aktivita jezuitov na poli kultúrneho rozvoja Slovenska v barokovom období, napriek rôznym kontroverzným názorom na ňu, je úctyhodná. Založenie a spravovanie univerzít v Trnave a v Košiciach, vydávanie kníh nielen náboženského, ale aj svetského charakteru a prínos v oblasti vedy nám v diachrónnom pohlade na historické udalosti dáva možnost̉ objektívneho pohladu na pôsobenie jezuitov na území dnešného Slovenska.

Hoci situácia na Slovensku v 16. a 17. storočí v katolíckej cirkvi bola kritická, rekatolizácia často nepostupovala pre individuálnu neschopnost’ jedinca priklonit’ sa k jednej alebo k druhej strane. S náboženstvom totiž súviseli aj sociálne či politické záujmy. Konfesijná príslušnost̉ majitela pôdy, dediny či panstva ešte stále určovala náboženskú príslušnost̉ ich členov, pretože stále platilo: „Cuius regio eius est religio.“

V tomto kontexte sa javí vydanie spevníka Cantus Catholici ako prezieravá snaha moderným spôsobom aktivizovat katolíkov. Totožnost’ zostavovatela spevníka bola neznáma až do začiatku 20. storočia, ked' ju v roku 1935 odkryl Stanislav Wiess-Nägel. Ako autora identifikoval jezuitu Benedikta Szőllősiho (Weiss-Nägel 1935, 427). Ten sa drží pri zostavovaní spevníka dobového úzu a na úvod spevníka zaraduje latinský predhovor, ktorý má plnit viaceré úlohy, okrem obligátnej pochvaly svojho mecenáša má obhájit’ samotnú existenciu a význam diela. V období baroka sa v slovenskom priestore objavujú aj prvé národné obrany a chvály ${ }^{2}$, medzi ktoré môžeme zaradit aj čast' spomínaného latinského predhovoru: „Náš panónsky národ je preslávený mnohými chválorečami a pamätihodnostami dávnych pokolení. Ked'za krála Svätopluka, ktorý mal sídlo na Belgrade, prilipol ku Kristovi hlásaním Kristovej viery apoštolskými mužmi Cyrilom a Metodom, hoci vynikal $v$ každom druhu zbožnosti, predsa viac $v$ žalospevoch. Vysvitá to z rozličných piesní, podivuhodne prispôsobených na cirkevné slávnosti alebo iné časy. Spomenutí svätí otcovia, ked'svätým krstom pripojili ku Kristovi Panónov s králom Svätoplukom, ba aj s Bulharmi, Moravanmi a s kniežatom Čiech Bořivojom, dosiahli od rímskeho pápeža Mikuláša I., aby národom, ktoré pokrstili, bolo dovolené konat' služby božie v ludovom jazyku. To vraj bolo potvrdené odpovedou, aby každý duch

2 Problematikou národných a jazykových obrán sa zaoberá monografia Jána Tibenského (1965) s názvom Chvály a obrany slovenského národa.

3 Uvádzame rozsiahlejší citát z predhovoru, aby sme naň mohli explicitne odkazovat. 
chválil Pána. Preto je hodnoverné, že i panónsky národ používal kedysi túto výsadu [...]“" (Minárik et al. 1997, 269-270) „[...] ako to možno uzatvárat zo zvyku, trvajúceho v niektorých kostoloch ešte i za našich čias, kde čiastka Kánonu sa pri oltári ludovou rečou odbavovala. A na chóre aj skutočne skoro vo všetkých panonských kostoloch tak sa odbavuje Kyrie, Gloria a Kredo. Tieto nábožné spevy si Panoni vždy natolko cenili, žeby si priamo povedal, že nenájdeš národa, čo by sa im v tom vyrovnal. Pri bohoslužbách $v$ kostoloch zhromaždení tak správne spievajú žalmy a piesne, žeby si ich od jedného mal za hotových spevákov. A čo sa v kostole naučili, to na hostinách a besedách, vo viniciach a po poliach sladkozvučným hlaholom prespevujú. Kedže však tieto spevy, Vysokodôstojný Pane ${ }^{4}$, mnoho trpely na svojej dávnej kráse tak neprajnostou času a chybným prepisovaním, ako i nepriatel'skými znetvoreninami a novotami nekatolíkov, podujal som sa ich na pôvodné znenie, aby sa obnovila zbožnost' panonského ludu, ktorá kedysi prekvitala“ (Weiss-Nägel 1997, 427).

Priamy odkaz na cyrilo-metodskú misiu je dôkazom jej dôležitosti pri koncipovaní národnej identity Slovákov, aj ked je zjavné uvedomovanie si, že ide o duchovné vlastníctvo viacerých slovanských národov. Vyzdvihovanie dosiahnutia ciel’a uznania d’alšieho bohoslužobného jazyka s pápežským schválením Mikuláša I. predstavuje ešte aj v čase baroka prijatelnú argumentáciu vzniku a existencie „ludového“ spevníka. Predhovor je aj ukazovatelom toho, ako sa vnímala duchovná pieseň a aký význam sa jej prikladal. Vyzdvihuje sa jej starobylý pôvod, oblúbenost’ medzi ludom a jej prenášanie mimo sakrálny priestor.

S ohladom na pôvod piesní sú barokové kancionály vlastne hybridnými ${ }^{5}$ dielami. Preberajú piesne umelého i ludového pôvodu, zahrnujú latinské i slovenské, resp. české piesne, siahajú po súdobo aktuálnych piesňach a rovnako po tradičných duchovných piesňach starých niekolko storočí. Práve pocit slovanskej spolupatričnosti vyplývajúci aj z vel'komoravskej tradície je pre zostavovatela zrejme jedným z dostatočných dôvodov pre preberanie piesní z českého prostredia. Preto je nevyhnutné poukázat na vzájomné vztahy českého a slovenského kultúrneho, duchovného a literárneho života pri preberaní duchovnej kancionálovej piesne. Je zjavná prepojenost’ slovenskej katolíckej kancionálovej tvorby 17. storočia s českou tvorbou vznikajúcou v tom istom období, ktorá sa demonštruje preberaním piesňového fondu českých kancionálov do kancionálov slovenských.

Na demonštráciu týchto vztahov sme si vybrali spevník Jiříka Hlohovského Písně katolické (1622). Časom vydania aj slohovým zaradením do barokového obdobia totiž najviac korešponduje so spevníkom Cantus Catholici (1655). Komparatívny spôsob by mal dostatočne objasnit', ako dochádzalo k preberaniu piesní z českého prostredia do slovenského, pričom pars pro toto rozanalyzujeme prípad spevníka, ktorý mal najviac spoločných piesní so slovenským spevníkom.

Vztahom českých a slovenských predbarokových a barokových spevníkov sa v literárnovednom, resp. literárnohistorickom výskume zatial nevenovala dostatočná pozornost'. Problematike sa okrajovo venujú len dve štúdie: prvou je už skoro storočie stará štúdia Jana Vilikovského (1935, 269-306) o spevníku Cantus Catholici a druhou príspevok Petra Ruskina (2002, 11-22).

Vilikovského štúdia rieši otázku vztahu spevníka Cantus Catholici k iným spevníkom v štvrtom oddiele štúdie (VI. Poměr Cantus Catholici k předlohám), do jej zorného uhla sa však dostáva len vztah spevníka Cantus Catholici a českého kancionála Písně katolické Jiř́ka Hlohovského. Velký priestor svojho bádania o spevníku Cantus Catholici venuje Vilikovský vztahu tohto katolíckeho spevníka k slovenskému evanjelickému spevníku Cithara Sanctorum v inom oddiele. Hoci sa jeho štúdia ako jedna z najrozsiahlejších a v podstate ako jediná zaoberá kancionálom Cantus Catholici z literárnohistorického pohladu a usiluje sa definovat jeho predlohy z dostupných známych

Týmto oslovením je myslený Juraj Soos, spišský kanonik a mecenáš, ktorému je spevník dedikovaný.

5 Viac o problematike barových spevníkov pozri v prácach M. Kerulovej, predovšetkým v publikácii Nahliadnutia do staršej slovenskej literatúry (1999). 
spevníkov slovenskej i českej proveniencie, a to z kancionálov katolíckych i evanjelických, prevládol v slovenskej historiografii názor, pretrvávajúci dlhý čas a paušálne opakovaný, že piesne zo spevníka Cantus Catholici boli vo vel'kej miere prebraté z rôznych vydaní evanjelickej Cithary Sanctorum (Holčík 1936, 309-324). ${ }^{6}$ Na možnost' odlišného vnímania vztahu týchto kmeňových konfesijných spevníkov poukazujeme v štúdii Cithara sanctorum a Cantus Catholici v literárnom kontexte slovenského baroka (Lauková 2008, 83-89), v ktorej sa zamýšlame nad možnostou iného prepojenia oboch spevníkov a poukazujeme na nezanedbatelný vplyv českých evanjelických a katolíckych spevníkov rovnako na Citharu Sanctorum, ako i Cantus Catholici, ako aj na iný mechanizmus preberania duchovných piesní z jedného kancionála do druhého. V týchto úvahách sme nadviazali práve na uvedenú štúdiu Jána Vilikovského.?

Dôvody preberania duchovných piesní z českého do slovenského literárneho a kultúrneho prostredia sú mnohoraké. Tento „prenos“ duchovného dedičstva fungoval na obidvoch stranách, a to rovnako $\mathrm{v}$ rámci katolíckej aj evanjelickej konfesie. V náčrte by sme ho mohli zhrnút do niekolkých téz, ktoré sú podla nášho úsudku platné pre obe konfesijné strany.

Piesňové repertoáre barokových kancionálov mali rovnaký európsky základ, z ktorého čerpali ich zostavovatelia. Obidve konfesie nadväzovali na piesňové bohatstvo všeobecnej cirkvi pred reformáciou, ako aj na zažitú tradíciu duchovného spevu na našom území. Reformácia priniesla dôraz na domáci jazyk a jeho používanie v liturgii, čo sa odrazilo práve v evanjelických spevníkoch. Na túto skutočnost’ potom tiež reagovala rekatolizačná snaha katolíckej cirkvi.

Na našom území máme z predbarokového obdobia doložené len rukopisné spevníky a zborníky zväčša svetskej poézie, v ktorých sa sporadicky objavujú záznamy duchovnej poézie, napr. Vietorisov kódex. Vydanie tlačeného spevníka predstavuje v barokovom období významný a ojedinelý čin na strane katolíckej cirkvi, najmä ak zoberieme do úvahy skutočnost', že k prvému vydaniu katolíckeho spevníka došlo roku 1655, druhé nasledovalo až o pol storočie neskôr, roku 1700, tlačené kancionály boli skôr zriedkavé (Minárik 1984, 165). Zostavovatel’ spevníka Cantus Catholici mohol pocitovat potrebu nejakého vzoru v domácom jazyku, podla ktorého by pri zostavovaní svojho spevníka postupoval.

Slovenská reformačná cirkev ako útočisko českej exulantskej inteligencie už od renesancie vsakovala podnety, ktoré prinášali z českého kultúrneho, duchovného a literárneho prostredia tamojší vyhnanci. Mnohí exulanti neprestávali po príchode na územie dnešného Slovenska tvorit', čoho príkladom je nielen literárna tvorba Jakuba Jakobea, ale z nášho pohladu aj najdôležitejší počin Juraja (Jiř́ka) Tranovského - kancionál Cithara Sanctorum (1636). Nazdávat’ sa, že Tranovský vytvoril svoj spevník bez predchádzajúcich väzieb na české prostredie, nie je s ohladom na existujúce väzby reálne, preto možno jeho nadväzovanie na českú literárnu tradíciu v duchovnej tvorbe pokladat za nevyvrátitelné.

Benedikt Szőllősi - zostavovatel' katolíckeho spevníka - bol v inej pozícii ako Juraj Tranovský, napriek tomu sa vplyvu českého prostredia nevyhol, práve naopak, vedome naň nadväzoval. Mohol sa navyše opierat’ o univerzálnost' katolíckej cirkvi, ktorá mu v istom zmysle slúžila ako záštita. Jej autorita a tradícia bola dostatočnou zárukou pri preberaní duchovných piesní z akéhokolvek národného prostredia, teda aj z českého či nemeckého, prípadne madarského. ${ }^{8}$

6 Príkladom takéhoto chápania vztahu katolíckeho a evanjelického spevníka je Holčíkova (1936, 309-324) štúdia s názvom Nakolko vplývala Cithara Sanctorum na Cantus Catholici?

7 Táto štúdia má reflexívny charakter a nekladie si za ciel' komplexne zmapovat’ spomínané vztahy, skôr naznačuje súvislosti a prepojenia kancionálovej tvorby barokového obdobia bez nánosu konfesionálnych predsudkov z jednej či druhej strany.

8 V tejto súvislosti musíme poznamenat, že hoci sú najmä na mad’arskej strane preferované tézy, že slovenský 
Vplyv českého prostredia na slovenský spevník Cantus Catholici môžeme vidiet’ z niekolkých hladísk. Predovšetkým z hladiska úzkych kontaktov moravských a slovenských klerikov i laikov a potom z hladiska prepojenia provincií niektorých katolíckych duchovných rádov, najmä jezuitského. Práve jezuitom biskup Peter Pázmaň vložil do rúk správu spomínanej Trnavskej univerzity, v ktorej prostredí, ako predpokladáme, sa zrodil spevník Cantus Catholici. Jeho zostavovatel' Benedikt Szőllősi bol jezuita.

Podnety univerzity na formovanie kultúrnych a literárnych vztahov Slovákov a Čechov (v kancionálovej tvorbe či v organizácii hudobného života v Trnave) sú zretelné. Na Trnavskej univerzite pôsobili profesori z Olomouca, ktorí ušli pred švédskymi vojskami, a navštevovali ju aj študenti z tohto mesta. Prepojenie Trnavskej univerzity s Olomoucom je o to významnejšie, o čo viac si uvedomíme, že Hlohovského kancionál s názvom Písně katolické bol vydaný roku 1622 v Olomouci. Je pravdepodobné, že študenti a profesori z Olomouca poznali a do Trnavy priniesli spomínaný Hlohovského spevník a rovnakou cestou sa k nám mohli dostat’ aj iné staršie české katolícke kancionály. Styky medzi predstavitelmi katolíckej cirkvi na českej i slovenskej strane boli známe, a preto aj táto cesta prechodu českých spevníkov na slovenskú stranu bola možná, resp. na základe našich historických znalostí pravdepodobná.

Preberaním piesní z českého prostredia sa vyznačujú obidva spevníky zostavené na slovenskom území - Cithara Sanctorum i Cantus Catholici. Za pozornost̉ však stojí skutočnost', ako s českým jazykovým materiálom dalej narábajú. Juraj Tranovský v Cithare Sanctorum používa výhradne češtinu a aj nasledujúce vydania, hoci sa do nich v rôznej miere dostávajú už i slovenské jazykové prvky, tento úzus viac-menej dodržiavajú. Evanjelická cirkev sa totiž snažila zachovat' integritu spoločenstva aj prostredníctvom jazyka, ktorý sa stal v časoch náboženského prenasledovania jedným z oporných bodov tejto konfesie.

Katolícky spevník Cantus Catholici na rozdiel od Cithary Sanctorum analogický jav nekopíruje: „Jazyk spevníka Cantus Catholici zachytáva totiž realizáciu základných postulátov normy predspisovnej slovenčiny postavenej na základoch odlišnosti od češtiny. Táto jazyková norma mala svoju gradáciu smerom $\mathrm{k}$ živej norme slovenčiny aj v tomto žánri náboženskej literatúry (duchovná pieseň), ako sme to mohli konštatovat pri analýze jazyka slovenskej piesne predspisovného obdobia“ (Krasnovská 2002, 28).

Spevník má 515 číslovaných strán. Okrem nich obsahuje na začiatku titulný list, na nasledujúcej dvojstrane je latinské schválenie vydania spevníka a tri citáty s nadpisom $K$ čemu neb: neb jak nastalo uživáni pisni. Na nečíslovaných stranách sa dalej uvádza obsah: Pořádek Tytulìw Pysny prwnjho Djlu, Pořadek Tytuli̊w Pysnj w Druhém Dílu, Pořádej Tytuliow Pysnj Třetýho Dylu. V krátkom oslovení ćitatela potom zostavovatel’ poukazuje na hudobnú stránku spevníka a poúča ho, ako pracovat' s nápevmi: „Poněwadž w těchto Pisněch částo se spomjna Obecnj Melodye neb Nota: A mnozy malau wědomost o nj magj Wěziž tedy že Obecná Melodye neb Nota gest když čtyř Wessové neb Rythmowé do gedné wrstwy neb Noty wcgádzý. A každý z těch Wrssiow gen osm Syllab w sobě obsahuge. Yakožro gsau ryto následugjcý Pjsně.“"

V nám dostupnej verzii spevníka ${ }^{9}$ sa za obsahom nachádza samostatne číslovaná čast', a to na stranách 1-48, so spoločným názvom Pysně O Cžtyřech posledných wěcech každého Cžlowěka s emotívnym obrázkom ludských ostatkov a rakvy. Zaujímavostou je, že táto čast’ sa nachádza aj na konci spevníka na stranách 416-464 so zhodným obsahom a rozsahom, pričom táto lokácia je uvedená aj v Pořádku (obsahu) spevníka. Ostáva otázkou, prečo sa uvedený oddiel nachádza už na začiatku spevníka, a rovnako aj to, prečo je v spevníku zaradený až dvakrát. Jednou

spevník Cantus Catholici je prekladom madarského spevníka, už Ján Vilikovský v spomínanej štúdii toto tvrdenie jednoznačne vyvrátil.

9 Táto verzia pochádza z Národnej knižnice Praha a bola dodaná na mikrofilme. 
z možností je, že išlo o tlačiarovu chybu alebo „prílišnú“ iniciatívu. Omnoho pravdepodobnejšie sa nám však vidí, že tento „čin“ zodpovedá autorskému zámeru v duchu barokového naturelu spevníka. Možno sa domnievat', že barokové tematizovanie smrti, márnosti, pominutelnosti, pekla a neba mohlo byt motiváciou zaradenia tejto časti pred všetky ostatné, ako aj jej duplicitného výskytu v spevníku. ${ }^{10}$

Na konci spevníka Písně katolické sa nachádza jedenást̉ nečíslovaných strán registra a jedna strana errata, dve strany citátov zo žalmov s dobovými ilustráciami a jedna strana s vydavatel'skými údajmi.

Obsah spevníka vo všeobecnosti určovalo rozdelenie cirkevného roka. Tento postup radenia piesní dodržiavali katolícke aj evanjelické spevníky „normatívneho“ rázu.

Pri porovnaní formálnej stránky slovenského spevníka Cantus Catholici Benedikta Szőllősiho a českého spevníka Písně katolické zostavovatela Jiř́ka Hlohovského možno postrehnút podobnosti, ktoré sa dajú interpretovat ako jedna z indícií, že zostavovatel' slovenského spevníka dôkladne poznal český spevník. Pri preberaní piesní však k nemu nepristupoval mechanicky, ale tvorivo, v medziach dobového úzu, pričom nepreberal všetky prvky formálnej podoby Hlohovského spevníka.

Prvé vydanie spevníka Cantus Catholici vyšlo bez udania miesta vydania ${ }^{11}$ roku 1655 . Počtom strán je tento spevník menší ako Písně katolické Jiříka Hlohovského. Rovnako ako český spevník má aj slovenský na titulnom liste uvedený rozsiahly názov:

CANTVS CATHOLICI Pýsne KATHOLICKE Latinské, y Slowenské: Nowé i Starodáwné. Z-kterymi Krestiané w-Panoňygi Na Wýročné Swatky, Slawnosti, pry Službe Boži, a w ginem obzwlásstnem času, z pobožnosti swé Krestianské ožýwagi. Nasledugý po tem, Pýsne na Katechismus: O Swátostech Nowého zakona. Letaňye rozličné na Wýchodi Cyrkewne, a nebProcessyge, a Putowaňy. Z.mnohú, pilnosti, ku potesseňy Lidu Krestianského, z-nowu zebrané, a wübec widané. S. Pawel $k$ Epheským Cap. 5. V.19. Naplňeňý budte Duchem Swatým, mluwýce samy sebe w Žalmých, a w-Chwalách, a w Pýsničkach duchowných spýwagýce, a chwálu wzdáwagýce w-srdcých swých Pánu. Cum facultate ILLUSTRISSIMI ac REVERENDISSIMI DOMINI, DOMINI GEORGII LIPPAI ARCHIEPISCOPI STRIGONIENSIS Regni Ungariae Primitis. A. M. D. G. B. V. M. O. SS. H. A. P. R. 1655.

Názov spevníka v porovnaní so spevníkom Písně katolické je obsiahlejší, zahŕňa aj výpočet obsahu spevníka a navyše obsahuje citát z Listu Efezanom.

Spevník Cantus Catholici má 320 číslovaných strán. Za titulným listom nasledujú dva citáty sv. Hrieronyma a sv. Chryzostoma. Na rozdiel od českého spevníka, ktorý obsahuje tri citáty, chýba v slovenskom spevníku prvý citát z Listu Kolosanom (Kol 3, 16); v českom spevníku je pôvodne uvedené: Ku Kolosen: 3. c 17. Pravdepodobnou príčinou toho, prečo Benedikt Szőllösi zvolil len dva citáty, je skutočnost', že citát z Nového zákona pridal už do titulného listu.

Na tretej, štvrtej a piatej nečíslovanej strane sa nachádza latinský predhovor venovaný Jurajovi Soosovi, prepoštovi u sv. Štefana a kanonikovi Spišskej kapituly. Tento latinský predhovor zostavovatela v českom spevníku nenájdeme.

10 So zaradením piesní o posledných veciach človeka na začiatok spevníka sa nestretávame pri žiadnom inom tu spomínanom kancionáli. Piesne či básne o posledných veciach človeka prikazoval zarad’ovat' dobový úzus na koniec textu, čo môžeme sledovat nielen v dobových spevníkoch, ale napríklad aj v Gavlovičovej Valaskej škole, v ktorej sú koncepty o posledných veciach človeka zaradené na záver.

11 Levoču ako miesto vydania identifikoval podla typografických znakov Ján Čaplovič (1972) vo svojej monografii Bibliografia tlačí vydaných na Slovensku do roku 1700. Druhé vydanie spevníka Cantus Catholici vyšlo už v Trnave roku 1700. 
$\mathrm{Na}$ šiestej a siedmej strane nasleduje obsah kancionála. Rozdelenie piesní v spevníku opät tradične zodpovedá priebehu liturgického roka, rovnako ako je to v Hlohovského spevníku.

Z obsahu spevníka je zrejmé, že Hlohovský rozdelil piesne do troch oddielov. Prvý oddiel zahŕňa piesne podla priebehu liturgického roka, druhý oddiel obsahuje piesne o Márii, anjeloch a v poslednom oddiele sa nachádzajú piesne všeobecné, žalmy a piesne s témou o posledných štyroch veciach človeka. Na rozdiel od Hlohovského rozdelenia spevníka zostavovatel' Benedikt Szőllősi nerozdeluje spevník na oddiely a necháva ho v jednom celku. Spevníky majú spoločné časti z liturgického obdobia, zahŕňajúce piesne adventné, vianočné, pôstne, velkonočné, piesne mariánske, žalmy, všeobecné piesne a piesne na rôzne príležitosti. Cantus Catholici obsahuje len jednu pieseň k svätému, a to k sv. Ignácovi z Loyoly, čo bolo aj pre Weiss-Nägela signálom, že jeho zostavovatelom by mohol byt jezuita.

Rozdielna je i grafická úprava spevníkov. V spevníku Písně katolické sa nachádzajú dobové rytiny, ktoré sú uvádzané latinským citátom žalmového verša, pod obrázkom je jeho český preklad. Dobové rytiny sa nachádzajú na konci každého dielu a na začiatku samostatnej časti o posledných veciach človeka. Odlišné je aj grafické oddelenie jednotlivých veršov v strofách i samotných strof. V Hlohovského spevníku sú piesne písané in continuo, jednotlivé strofy sú od seba oddelené grafickými značkami a verše zvyčajne lomkou. V spevníku Cantus Catholici sú strofy oddelené odsekmi, každá strofa začína v novom riadku.

Netypickým počinom je krátky historický exkurz v spevníku Písně katolické na stranách 91-92 a 102-103. V prvom prípade ide o poučenie o tom, prečo na Vianoce kňazi navštevujú svojich veriacich. Túto tradíciu Jiř́ík Hlohovský odvodzuje zo stredoveku, ked' knieža Břetislav a Kosma, pražský biskup v 11. storočí, nariadili kňazom navštevovat’ počas Vianoc veriacich. So sebou mali mat kríž alebo pozostatky nejakého svätého a podla reakcií veriacich mali rozpoznávat, kto je krestanom a kto sa vrátil naspät k pohanstvu: „O starodáwnych takowých zwyklostech pýsse [...] že za Knýžete Břetislawa a Kosmy Biskupa dewáteho Pražského mnozý se od Křestianstwa na spět k wýwratu pohanskému wraceli: pročež z napomenutj Biskupského poručilo Knýže..." (Hlohovský $1622,91)$.

V podobnom duchu je napísaný aj druhý exkurz. Upozorňuje na to, akej vážnosti sa sviatok Troch králov v minulosti tešil, pričom sa odvoláva na starodávnu tradíciu návštevy kostola so sviečkou práve $\mathrm{v}$ tento deň. Kto sa podla tradície nedostavil do kostola, bol pokladaný za pohana: „O Slawnosti této Kteráž w starých zrýzených zemských Margkrabstwý Morawského gmenuge se (na Swýčky) wůbec wědomo gest. Že u starodáwnych Křstianưw w takéwé wážnosti byla že kdožby se dnessnýho Swátku, w Kostle při Mssy swaté, s rozžatau Swýcy pobožně nedal widěti: Ten za nestaleho w Wjre Křestianské gmjn a držán byl [...]“ (Hlohovský 1622, 102).

Takéto krátke vysvetlenia miestnych tradícií sa nenachádzajú v iných spevníkoch a neprebral ich ani Sölőši do spevníka Cantus Catholici. Pravdepodobne tak nemohol urobit preto, že ide o odvolanie sa na starú moravskú tradíciu, ktorá na území Slovenska neexistovala.

Formálna stránka oboch komparovaných katolíckych spevníkov poukazuje na to, že napriek podobnostiam, ktoré by sme mohli pripisovat dobovému úzu vydávania kancionálovej literatúry duchovného rázu, si oba spevníky zachovávajú vlastné špecifiká.

Existenciu spoločných piesní v českých a slovenských spevníkoch môžeme postrehnút predovšetkým v textovej rovine slovenského spevníka. Práve pri skúmaní ich spoločných čŕt je komparatívna metóda najefektívnejšia, pretože pri porovnávaní možno odhalit, či piesne v oboch spevníkoch majú obsahovú aj formálnu stránku rovnakú, alebo možno určit, či pieseň je prekladom, imitáciou, nejakou formou transformácie (tematickou alebo žánrovou), kontamináciou, abreviáciou.

Obidva skúmané spevníky - slovenský Cantus Catholici i české Písně katolické-, pochádzajú síce $\mathrm{z}$ dvoch rôznych národných a kultúrnych lokalít, no spoluurčujú diapazón európskeho barokového 
kancionálového bohatstva. Starší spevník Písně katolické (1622), zostavený Jiříkom Hlohovským a vydaný v Olomouci, sa stal jedným z inšpiračných zdrojov novšieho spevníka Cantus Catholici (1655), zostaveného Benediktom Szőllősim a vydaného v Levoči. Rozdiel tridsiatich troch rokov, ktoré uplynuli medzi ich vydaniami, je dostatočne dlhým časom na to, aby sa kniha, a to aj v čase baroka, stala známou a mohla byt vzorom medzitextového nadväzovania pri koncipovaní iného diela - v našom prípade prvého kancionálového opusu katolíckej proveniencie, edične pripraveného a vydaného na území dnešného Slovenska.

Zostavovatel’ českého spevníka Písně katolické Jiř́k Hlohovský pri vydávaní svojho spevníka mohol nadviazat’ na tradíciu českej katolíckej hymnografie (vrátane hymnografie nekatolíckej), ktorej výsledkom boli už v 1. polovici 17. storočia tlačené kancionály. Táto tradícia bola naozaj pozoruhodná: „Rozsah české evangelické a katolické hymnografie doby humanismu a baroka lze odhadnout na přibližně pět tisíc textových jednotek“ (Malura et al. 2006, 141-154). Zvlášt významný je Kancyonál To gest: Sebránij Spěwưw Pobožných (1601), pretože vychádza pred Hlohovského spevníkom, rovnako dôležitým faktorom bola čeština, ktorá vytvárala editorovi spevníka dostatočné zázemie na to, aby pri svojom editorskom počine nemusel upravovat jazyk piesní a mohol sa zamerat' na ich teologickú, estetickú a morálnu funkciu.

V diametrálne odlišnej situácii sa však nachádzal zostavovatel’ prvého slovenského tlačeného spevníka Cantus Catholici jezuita Benedikt Szőllősi. Na území dnešného Slovenska do dátumu vydania jeho spevníka nebol vytlačený žiaden katolícky spevník. Všetky záznamy duchovnej piesne boli realizované len $\mathrm{v}$ rukopisných spevníkoch a zborníkoch, a to nezriedka s prevahou svetskej tematiky - príkladom je Vietorisov kódex.

Ani náboženská a spoločenská situácia na našom území nebola v čase vydania spevníka Cantus Catholici priaznivá. Na území Slovenska mala v tomto čase prevahu protestantská cirkev napriek tomu, že náboženstvom vládnucej panovníckej dynastie Habsburgovcov bol katolicizmus. Tento stav nakoniec viedol k ustanoveniu, ktoré vyplynulo z Trnavskej synody (1629), že je nevyhnutné zostavit katolícky spevník duchovnej poézie, ktorý by obsahoval pravoverné piesne $\mathrm{v}$ katolíckom duchu. Toto nariadenie prišlo v čase, ked’ si neudržatel’ný stav v rámci katolíckej cirkvi začínajú uvedomovat aj vyšší cirkevní predstavitelia. Z dostupných materiálov nie je možné zistit', ako sa Benedikt Szőllősi dostal k zostaveniu požadovaného spevníka, no s vysokou mierou pravdepodobnosti platí, že v čase vydania spevníka bol už jezuitom a skúseným kňazom.

Časový odstup dvadsiatich šiestich rokov od rozhodnutia synody vydat spevník po jeho vytlačenie bol dlhý, preto nemôžeme s úplnou určitostou tvrdit, že spevník Cantus Catholici vyšiel ako priama reakcia na nariadenie Trnavskej synody. O to viac, že roku 1651 vychádza madarský spevník s tým istým názvom. Ak prijmeme tézu, že zostavovatelom oboch spevníkov je Benedikt Szőllősi, ako aj fakt, že slovenský spevník nie je doslovným prekladom madarského spevníka, ale samostatným tvorivým aktom, musíme pokladat jeho zostavovatela za mimoriadne schopného a erudovaného nielen v oblasti teologickej a hymnologickej, ale aj v oblasti lingvistickej. Najmä ak si uvedomíme, že vydanie mad’arského spevníka ho zásadne neovplyvnilo pri zostavovaní spevníka slovenského. Pri jeho zostavovaní, naopak, využil dostupné české spevníky - a spomedzi nich predovšetkým Písně katolické -, z ktorých preberá najviac piesní, podla našich zistení až 129.

Pri zistovaní dôvodov, ktoré ho k výberu piesní viedli, sa musíme vrátit k latinskému predhovoru Benedikta Szőllősiho k slovenskému spevníku. Píše v ňom:

„Kedže však tieto spevy, Vysokodôstojný Pane, mnoho trpeli na svojej dávnej kráse tak neprajnostou času a chybným prepisovaním, ako i nepriatel'skými znetvoreninami a novotami nekatolíkov, podujal som sa uviest' ich na pôvodné znenie, aby sa obnovila zbožnost' panónskeho ludu, ktorá kedysi prekvitala“ (Weiss-Nägel 1935, 426).

Hladanie vhodných piesní do spevníka Cantus Catholici teda viedlo Benedikta Szőllősiho $\mathrm{k}$ tomu, aby siahol po rôznych piesňach a vybral $\mathrm{z}$ nich také, ktoré boli vieroučne pravoverné 
a zároveň spĺňali podmienku autentickej historickosti a oblúbenosti u ludí na území dnešného Slovenska. Jasne profilovaná vieroučná stránka spevníka ho viedla $\mathrm{k}$ tomu, že dôsledne pristupoval ku každej piesni, uvedomujúc si, že koncipuje oficiálny spevník katolíckej cirkvi, ktorý musí následne prejst' cirkevnou cenzúrou.

Podoba piesňového výberu kancionála či spevníka zodpovedala zámeru autora. Zostavovatel' musel dbat na správny výber piesní, na ich usporiadanie či zoradenie do jednotlivých oddielov a častí, jeho úlohou bolo teda prihliadat na tektoniku spevníka i na jeho teologickú pravovernost' a, ako sme už uviedli, rovnako na to, aby piesne boli piesňami živými, ktoré percipient poznal a mal ich v oblube. Výber piesní preto nebol náhodný, určovali ho také činitele ako autorská estetická koncepcia spevníka, tematické rozvrstvenie piesní, formálne rozčlenenie spevníka, rôzna doba vzniku piesní, dobová „popularita“ piesní či kritérium katolicizmu.

Ak sa v tomto kontexte zamyslíme nad funkciou a poslaním dvoch porovnávaných spevníkov, nemôže nám uniknút indícia, ktorá podla nášho názoru vypovedá o rozdielnom poslaní komparovaných spevníkov. Skutočnost', že český spevník neudáva na začiatku jednotlivých častí piesne Glória, Kyrie a Krédo, teda ich a priori nevyčleňuje a neoznačuje, nám naznačuje, že zostavovatel' spevníka Písně katolické Jiř́ík Hlohovský pravdepodobne nepocitoval potrebu určovat’ osobitne piesne spievané v rámci liturgických obradov, čo mohlo vyplývat z ich už ustáleného a dlhodobého využívania v náboženskom obrade. V porovnaní so spevníkom Cantus Catholici je zaujímavé, že niektoré piesne spoločné pre oba spevníky sa v slovenskom spevníku označujú ako piesne určené na niektorú čast' liturgie (Glória, Krédo, Kyrie).

Ako prelomový spevník katolíckej proveniencie musel Cantus Catholici splńat aj kanonizačné kritériá. Je preto pravdepodobné, že vymedzené časti omše - myslíme tým Glóriu, Krédo a Kyrie - boli spievané počas liturgie v jazyku veriacich, ale neoficiálne, pretože katolícka cirkev trvala na záväznosti latinského jazyka náboženského obradu. Vyjadruje sa k tomu aj sám zostavovatel' spevníka vo svojom latinskom predhovore: „[...] ako to možno uzatvárat zo zvyku, trvajúceho $v$ niektorých kostoloch ešte i za našich čias, kde čiastka Kánonu sa pri oltári ludovou rečou odbavovala. A na chóre aj skutočne skoro vo všetkých panónských kostoloch tak sa odbavuje Kyrie, Gloria a Kredo" (Weiss-Nägel 1935, 426-430).

V praxi to mohlo vyzerat tak, že kňaz pri oltári spieval príslušné časti v latinčine a lud ich spieval v slovenčine. Azda toto bolo dôvodom, prečo Benedikt Szőllősi zaradil uvedené piesne na začiatok jednotlivých častí spevníka. Takéto vyčlenenie sa totiž netýka všetkých piesní, len piesní liturgického roka a piesní všeobecných.

Ďalšou indíciou, na základe ktorej sa možno domnievat, že dva komparované spevníky plnili rozdielne poslanie, môže byt počet latinských piesní, ktoré obsahujú. Spevník Písně katolické obsahuje 24 latinských piesní, z toho 10 je zaradených do dodatku na konci spevníka, zostávajúce latinské piesne sú najviac zastúpené v kapitole s vianočnými piesňami (7), pričom latinská pieseň aj jej český preklad je pod tým istým notovým záznamom. Ostatné latinské piesne sú uvádzané pred českým prekladom. Ak sa v spevníku Písně katolické vyskytujú latinské piesne bez následného prekladu len v dodatku, tak v spevníku Cantus Catholici je v kapitole vianočných piesní celá čast’ zostavená výhradne $\mathrm{z}$ latinských piesní.

Spevník Cantus Catholici obsahuje nepomerne viacej latinských piesní - až 65. Ak sme prijali tézu, že Hlohovského spevník slúžil Benediktovi Szőllősimu ako jeden z hlavných vzorov, vzniká otázka, prečo do svojho spevníka zaradil takmer trojnásobne vyšší počet latinských piesní, t. j. aj piesne z iných zdrojov ako zo spevníka Písně katolické. Spevník Cantus Catholici bol oficiálnym spevníkom katolíckej cirkvi a na dlhý čas aj jediným takýmto opusom v barokovom kancionálovom kontexte na území dnešného Slovenska. Musel preto kopírovat’ snahu katolíckej cirkvi usmerňovat veriacich $\mathrm{v}$ speve, či už v chrámoch, na pobožnostiach, pútach alebo v nesakrálnom priestore, a súčasne zachovávat kánon a predpisy katolíckej cirkvi. Tieto požiadavky sa prejavili, 
ako sa domnievame, v kvantite latinských piesní, ktoré nadväzovali na latinskú liturgiu a tradíciu. Ich preklady potom možno pokladat za snahu približit' sa k jednoduchému veriacemu.

Spevník Cantus Catholici, ako sme už uviedli, má práve so spevníkom Písně katolické najviac spoločných piesní - až 129. Často sa uvádza nesprávny predpoklad, že toto je počet prebraných piesní, t. j. piesní, ktoré Szőllősi jednoducho prevzal z českého spevníka, alebo sa používa aj termín „pochádzajú“. Oba tieto termíny môžeme pokladat za nepresné, pretože nevypovedajú o tom, akým spôsobom zostavovatel’ spevníka Cantus Catholici pracoval s bohatstvom piesní zaradených do spevníka, resp. či sa piesne spoločné pre oba spevníky dostali do spevníka Cantus Catholici $\mathrm{z}$ iného prameňa.

Pri porovnávaní piesní oboch spevníkov je zrejmé, že prístup Benedikta Szőllősiho k spevníku Písně katolické bol kritický a tvorivý. Môžeme odmietnut tvrdenia, že Szőllösi piesne zo spevníka Jiř́ka Hlohovského prebral len mechanicky.

Formálna stránka obidvoch spevníkov je rozdielna, i ked’ zachovávajú nevyhnutnú inštitucionálnu podobu rozdelenia piesní do častí radených podla priebehu liturgického roka. Konkrétnym rozdelením a zoskupením piesní sa oba spevníky od seba odlišujú. Hlohovský volí rozdelenie do troch oddielov, kým Szőllősi ponecháva piesne bez členenia. Časti v prvom oddiele spevníka Písně katolické a spevníka Cantus Catholici sú identické. Oba spevníky sa začínajú častami adventné piesne, vianočné piesne (obsahujúce piesne na Hromnice, na Troch králov, na Nový rok), pôstne piesne a piesne o umučení Krista, velkonočné piesne, piesne o nanebovstúpení Pána, mariánske piesne, turíčne piesne, piesne na deň Božieho Tela, piesne k Svätej Trojici a piesne spievané v deň posvätenia chrámu. Spoločné sú aj katechetické piesne a litánie. Len jedna pieseň v časti $O$ posledných veciach človeka sa v spevníku Cantus Catholici nenachádza, a to pieseň o márnosti sveta Cur mundus militat (latinská verzia a jej český, resp. slovenský preklad). V druhom oddiele spevníka Písně katolické sú zaradené kapitoly piesní, ktoré sa v spevníku Cantus Catholici nenachádzajú, a to napríklad piesne o anjeloch, apoštoloch, svätých, vyznávačoch, pannách a vdovách a iné. Aj z tohto krátkeho výpočtu je zrejmé, že Benedikt Szőllősi mal vlastnú predstavu o obsahovom zložení spevníka. Vyberá si piesne, ktoré sú predpokladom inštitucionálneho charakteru spevníka.

Osobitý prístup Benedikta Szőllősiho sa vo formálnej stránke spevníka Cantus Catholici prejavil vo viacerých aspektoch. V úvode spevníka napríklad uverejňuje citáty, ktoré sú síce totožné s tromi citátmi zo spevníka Písně katolické, nezaraduje ich však všetky rovnako, za titulným listom zostali dva citáty, tretí Benedikt Szőllősi zaraduje do názvu celého spevníka.

Ideu latinského predhovoru, v ktorom poukazuje na slávnu minulost' a postavenie duchovnej piesne v kontexte doby, preberá zas z iného českého spevníka, a to z Rozenplutovho kancionála (1601) - ten vo svojom predhovore spomína aj sv. Cyrila a Metoda.

Z funkčného hladiska je symptomatický výber piesní, ktoré sa Benedikt Szőllősi rozhodol do svojho spevníka zaradit. Mal ambíciu vytvorit spevník, ktorý by sa mohol stat záväzným spevníkom pre katolícku cirkev na území dnešného Slovenska, a teda musel tejto ašpirácii prispôsobit aj jeho obsah. Zaradil doň nielen piesne liturgického roka, pričom pochopitelná je kvantita adventných a vianočných piesní, ale aj piesne „na katechizmus“, t. j. piesne, ktoré vysvetlujú náuku katolíckej cirkvi a jej doktrínu - piesne o desiatich Božích prikázaniach, o troch krestanských cnostiach - láske, nádeji a viere -, piesne o siedmich sviatostiach - o krste, birmovaní, sviatosti oltárnej, sviatosti zmierenia, pomazaní chorých a sviatosti kňazstva. Táto čast’ je rovnaká ako v spevníku Písně katolické a jednotlivé katechetické piesne sa navzájom neodlišujú - môžeme ich hodnotit ako piesne rovnaké bez akýchkolvek významových alebo sémantických posunov.

Zaradenie piesní k istému tematickému okruhu v Hlohovského spevníku nepokladá Szőllősi za záväzné. V spevníku Cantus Catholici môžeme nájst’ prípady, ked’ sa pieseň figurujúca v istej časti českého spevníka nachádza v inej časti slovenského spevníka. 
Príkladom je čast', ktorá obsahuje litánie a piesne spievané na rôznych pútach (Szőllősi 1655, 265-310). Český spevník takúto kapitolu vôbec neobsahuje, litánie sú zaradené do rôznych iných kapitol podla tematiky. Nachádzajú sa napríklad ako samostatný text pred piesňami o posledných veciach človeka, medzi piesňami na deň Obetovania Pána (pieseň Plesanie sv. Bernarda) či medzi piesňami o Panne Márii (loretánske litánie).

Podobný postup Benedikt Szőllősi volí aj pri práci so žalmami. Kým Hlohovského spevník obsahuje čast’ s názvom Piesne na sedem žalmov kajúcich pripisovaných Dávidovi, Szőllősiho výber v kapitole s rovnakým názvom obsahuje len jeden Dávidov kajúci žalm, a to žalm, ktorý je ale zaradený v kapitole s piesňami „obecnými“. V tejto časti sú uvedené iné žalmy.

S ohladom na komunitu sú v spevníku Cantus Catholici i Písně katolické nosnými piesňami piesne adventné a vianočné, čo svedčí o ich mimoriadnej oblube medzi ludom. Práve adventnú a vianočnú tematiku môžeme považovat za jednu z najkatolíckejších v duchovnej poézii. Pri nej je najviac viditelný individuálny prístup zostavovatela k rozsiahlemu textovému materiálu, ktorý pri zostavovaní spevníka musel nevyhnutne poznat a podrobit selekcii.

Zo zastúpenia adventných a vianočných piesní v oboch spevníkoch, ako aj z porovnania zhodných a odlišných piesní je zrejmé, že v spevníku Cantus Catholici sa nachádza viac adventných piesní ako v spevníku Písně katolické, a to v pomere 21 : 18 (prvý údaj zahŕňa počet piesní v spevníku Cantus Catholici, druhý v spevníku Písně katolické). Z tohto počtu je 7 spoločných piesní. Približne tretina piesní v oboch spevníkoch je rovnaká. To znova potvrdzuje, že zostavovatel' spevníka Cantus Catholici Benedikt Szőllősi nepokladal český spevník za spevník „modelovo“ záväzný.

Pri porovnávaní vianočných piesní v oboch spevníkoch možno zase zistit, že v spevníku Cantus Catholici je 75 oproti 46 piesňam v spevníku Písně katolické. Spoločných piesní v oboch spevníkoch je 27, čo predstavuje v spevníku Cantus Catholici cca 36 \%, ale v spevníku Písně katolické až cca $60 \%$ z celkového počtu piesní. To znamená, že skoro dve tretiny piesňového fondu vianočných piesní v českom spevníku sa nachádzajú v spevníku slovenskom. Treba mat’ však na zreteli, že značnú čast' vianočných piesní tvoria v spevníku Cantus Catholici piesne latinské, a to takmer polovicu. Všetky latinské piesne z českého spevníka sa nachádzajú v slovenskom spevníku. Spoločné piesne v národných jazykoch potom tvoria cca $45 \%$ piesní v oboch spevníkoch.

Z výskumu oboch spevníkov je zrejmé, že zostavovatel spevníka Cantus Catholici pristupoval $\mathrm{k}$ výberu a úprave piesní špecificky, s ohladom na zameranie spevníka a jeho poslanie. Kedže spevník bol určený na spievanie pre lud, prispôsobuje jeho vnímaniu výber piesní známych a oblúbených (vianočné, adventné, pôstne...), pričom ich upravuje podla tradície a kontinuity katolíckej piesne na území dnešného Slovenska. Piesne, ktoré tematicky opisujú a vysvetlujú učenie a doktrínu katolíckej cirkvi, však necháva v nezmenenej podobe - v takej, v akej sú publikované a kanonizované v spevníku Písně katolické Jiříka Hlohovského. V týchto piesňach Benedikt Szőllösi nezasahuje do ich obsahovej ani formálnej stránky.

Piesne, ktoré sa zhodne vyskytujú v oboch spevníkoch, by sme mohli rozdelit do troch skupín. Toto rozdelenie zodpovedá podobe ich úprav a tematických i formálnych rozdielov:

Do prvej skupiny patria piesne, ktoré sa v oboch spevníkoch nachádzajú v nezmenenej podobe. Pri ich porovnávaní z obsahového a formálneho hladiska sme zistili, že neprešli žiadnou úpravou (samozrejme, okrem ich upravenia v prospech slovenskej jazykovej „normy“). Ako sme už uviedli, sú to predovšetkým piesne vieroučné a litánie a čast̉ mariánskych piesní.

Do druhej skupiny môžeme zaradit piesne, ktoré sa v spevníku Cantus Catholici nachádzajú $\mathrm{v}$ abreviačnej, t. j. skrátenej podobe. Sú to piesne, v ktorých sú v porovnaní s ich podobou v spevníku Písně katolické vynechané strofy (zvyčajne posledné), no z obsahovej stránky nedochádza $\mathrm{k}$ sémantickým posunom.

Do tretej skupiny sa začleňujú piesne, ktoré sa v spevníku Cantus Catholici v porovnaní s ich verziou v spevníku Písně katolické nachádzajú v amplifikovanej verzii, resp. zmeny sú evidentné 
v obsahovej rovine piesňového textu. Do tejto skupiny patria texty piesní z liturgickej časti piesňového repertoáru spevníka, ako sme sa o nich už zmienili.

Na základe výskumu piesňového korpusu spevníka Cantus Catholici a jeho možných zdrojov, či už z línie českej katolíckej kancionálovej tvorby, alebo z línie slovenskej evanjelickej duchovnej piesne, môžeme konštatovat, že je stále na nedostatočnej úrovni základný heuristický výskum slovenskej barokovej hymnológie, a to rovnako spevníkov katolíckej i evanjelickej ${ }^{12}$ proveniencie. V českom literárnom kontexte je situácia trochu iná - bádatelom sa už podarilo spracovat’ aspoň čast' z dostupného spevníkového bohatstva. Hymnologický výskum na Slovensku nemá $\mathrm{k}$ dispozícii, na rozdiel od českého výskumného kontextu, register piesní podla incipitov a register prameňov. Musí sa opierat výhradne o individuálny bádatel’ský výskum originálnych textových jednotiek, v lepšom prípade tlačených kancionálov v švabachu, v horšom prípade rukopisných spevníkov a zborníkov.

Je zrejmé, že český spevník bol naozaj zdrojom slovenského spevníka, ale toto nadväzovanie bolo tvorivé a originálne. Uvedomujeme si, že problematika medzitextového nadväzovania nemôže byt úspešne skúmaná, kým neprebehne dôkladný heuristický výskum kancionálovej tvorby slovenskej aj v prepojenosti na spevníky českej proveniencie.

Cyrilo-metodský vplyv sa $\mathrm{v}$ baroku prejavuje najmä $\mathrm{v}$ momentoch obhajoby národa a jazyka. S príchodom osvietenských ideí sa objavujú diela historického charakteru Juraja Papánka a Juraja Sklenára, ktoré napriek mnohým nepresnostiam, ktoré obsahujú, významným spôsobom ovplyvnia vývin uvažovania o problematike a stanú sa inšpiračným zdrojom autorov beletrie a prehíbenia cyrilo-metodskej tradície $\mathrm{v}$ ich dielach ako tradície slovanskej - slovenskej - národnej - obrodeneckej. ${ }^{13}$

\section{REFERENCES}

\section{Primary sources}

CANTVS CATHOLICI Pýsne KATOLICKE Latinské, y Slowenské: Nowé i Starodáwné. Z-kterymi Krestiané w-Panoňygi Na Wýročné Swatky, Slawnosti, pry Službe Boži, a w ginem obzwlásstnem času, z pobožnosti swé Krestianské ožýwagi. Nasledugý po tem, Pýsne na Katechismus: O Swátostech Nowého zakona. Letaňye rozličné na Wýchodi Cyrkewne, a neb Processyge, a Putowaňy. Z.mnohú, pilnosti, ku potesseňy Lidu Krestianského, z-nowu zebrané, a wůbec widané. Levoča 1655. Slovenská národná knižnica, Sign.: SD 10375 D 1. Archív Spolku sv. Vojtecha, fasc. 200/1.

CANTVS CATHOLICI Pýsne KATOLICKE Latinské, y Slowenské: Nowé i Starodáwné. Z-kterymi Krestiané w-Panoňygi Na Wýročné Swatky, Slawnosti, pry Službe Boži, a w ginem

12 Treba však podotknút, že problematike evanjelického spevníka Cithara Sanctorum sa v slovenskom literárnohistorickom výskume venovala väčšia pozornosṫ (Minárik 1990, 172-194).

13 Pri citovaní úryvkov zo starých textov sme sa rozhodli pre transliteráciu textov zo švabachu. Jedným z dôvodov takéhoto rozhodnutia je snaha zachovat autenticitu starých textov. Ako další problematický jav sa ukázalo používanie a zapisovanie dobových mien (Gáfriková 2006, 215-222). Zjednotenie písania historických mien bude dlhodobým procesom, ktorý sa nevyhne odbornej diskusii nielen v radoch lingvistov, ale aj v radoch literárnych historikov a historiografov. V odborných textoch sa objavujú viaceré upravené podoby mena zostavovatela spevníka Cantus Catholici Benedikta Szőllősiho (Sőlőši, Szölösy), kedže doteraz neexistuje všeobecne platný úzus jeho písania. Rozhodli sme sa preto používat podobu Benedikt Szöllősi. 
obzwlásstnem času, z pobožnosti swé Krestianské ožýwagi. Nasledugý po tem, Pýsne na Katechismus: O Swátostech Nowého zakona. Letaňye rozličné na Wýchodi Cyrkewne, a neb Processyge, a Putowaňy. Z.mnohú, pilnosti, ku potesseňy Lidu Krestianského, z-nowu zebrané, a wůbec widané. Trnava 1700. Slovenská národná knižnica, sign. SD 6438 D1. Archív Spolku sv. Vojtecha, fasc. 200/2.

HLOHOVSKÝ, JIŘÍK: Pjsně Katholické k Wýročnjm Slawnostem k Památkám Bozjch S. S. a k rozličným časům pobožnosti Křestianské. S mnohoau a bedliwau snažnostj: nežli kdy prwé, sebrané, přehljdnuté neřesti zprosstěné Starobylé pobožnosti nawrácené a wůbec wydané. Skrze Giřjika Hlohowského. S pbzwlásstnjm dowolenjm a schwálenjm G: W. K. M. Frant: Kardynala z Dytrychssteyna Biskupa Olomauckého. (Wytisstění w Olomaucy, v Mathyásse Handle Léta) M. DC. XXII. = 1622. Národní knižnice, Praha 54 K 20.376 přiv.

\section{Secondary sources}

Čaplovič, Ján. 1972. Bibliografia tlačí vydaných na Slovensku do roku 1700. Martin.

Gáfriková, Gizela. 2006. Zabúdané súvislosti. Bratislava.

Holčík, Juraj. 1936. Nakol'ko vplývala Cithara Sanctorum na Cantus Catholici? Odtlačok z Tranovského sborníka, Podielovej knihy Hurbanovej evanjelickej spoločnosti literárnej číslo 40, 309-324.

Kerulová, Marta. 1999. Nahliadnutia do staršej slovenskej literatúry. Nitra.

Krasnovská, Elena. 2002. České predlohy a ich odraz v jazyku duchovných piesní spevníka Cantus Catholici. In Cantus Catholici a duchovná pieseň 17. storočia v strednej Európe. Bratislava, 23-42.

Lauková, Silvia. 2008. Cithara sanctorum a Cantus Catholici v literárnom kontexte slovenského baroka. In Cithara sanctorum 1636 - 2006. Zborník prác z vedeckej konferencie, ktorá sa konala pri príležitosti 370. výročia 1. vydania kancionála v dňoch 22. a 23. novembra 2006 v Liptovskom Mikuláši a v Liptovskom Jáne. Martin, 83-89.

Malura, Jan. 2006. Česká hymnografie raného novověku ve stř̌edoevropském kontextu. In Fedrová, Stanislava (ed.). Otázky českého kánonu. Sborník příspěvků z III. kongresu světové literárněvědné bohemistiky. Hodnoty a hranice. Svět v české literatuře, česká literatura ve světě. Sv. 1. Praha, 141-154.

Minárik, Jozef et al. 1997. Z klenotnice staršieho slovenského písomníctva. Bratislava, 269-270.

Minárik, Jozef. 1984. Baroková literatúra. Bratislava.

Minárik, Jozef. 1990. K problematike staršej slovenskej literatúry. In Slovenská literatúra 37/2, 172-194.

Ruščin, Peter. 2002. Estetické a hudobnoštýlové špecifiká spevníka Cantus Catholici. In Cantus Catholici a duchovná pieseň 17. storočia v strednej Európe. Bratislava, 11-22.

Tibenský, Ján. 1965. Chvály a obrany slovenského národa. Bratislava.

Vilikovský, Jan. 1935. Cantus Catholici. In Bratislava 9, 269-306.

Vlček, Jaroslav. 1890. Dějiny literatúry slovenskej. Turčiansky Sv. Martin.

Weiss-Nägel, Stanislav. 1935. Kto je autorom spevníka Cantus Catholici? In Kultúra 7, 426-430. 
doc. PhDr. Silvia Lauková, PhD.

Constantine the Philosopher University in Nitra Faculty of Arts

Department of Slovak Language and Literature Štefánikova 67

94974 Nitra

Slovakia

slaukova@ukf.sk

PhDr. Petra Kaizerová, PhD.

Constantine the Philosopher University in Nitra Faculty of Arts

Department of Slovak Language and Literature Štefánikova 67

94974 Nitra

Slovakia

pkaizerova@ukf.sk 


\section{Príloha / Appendix}

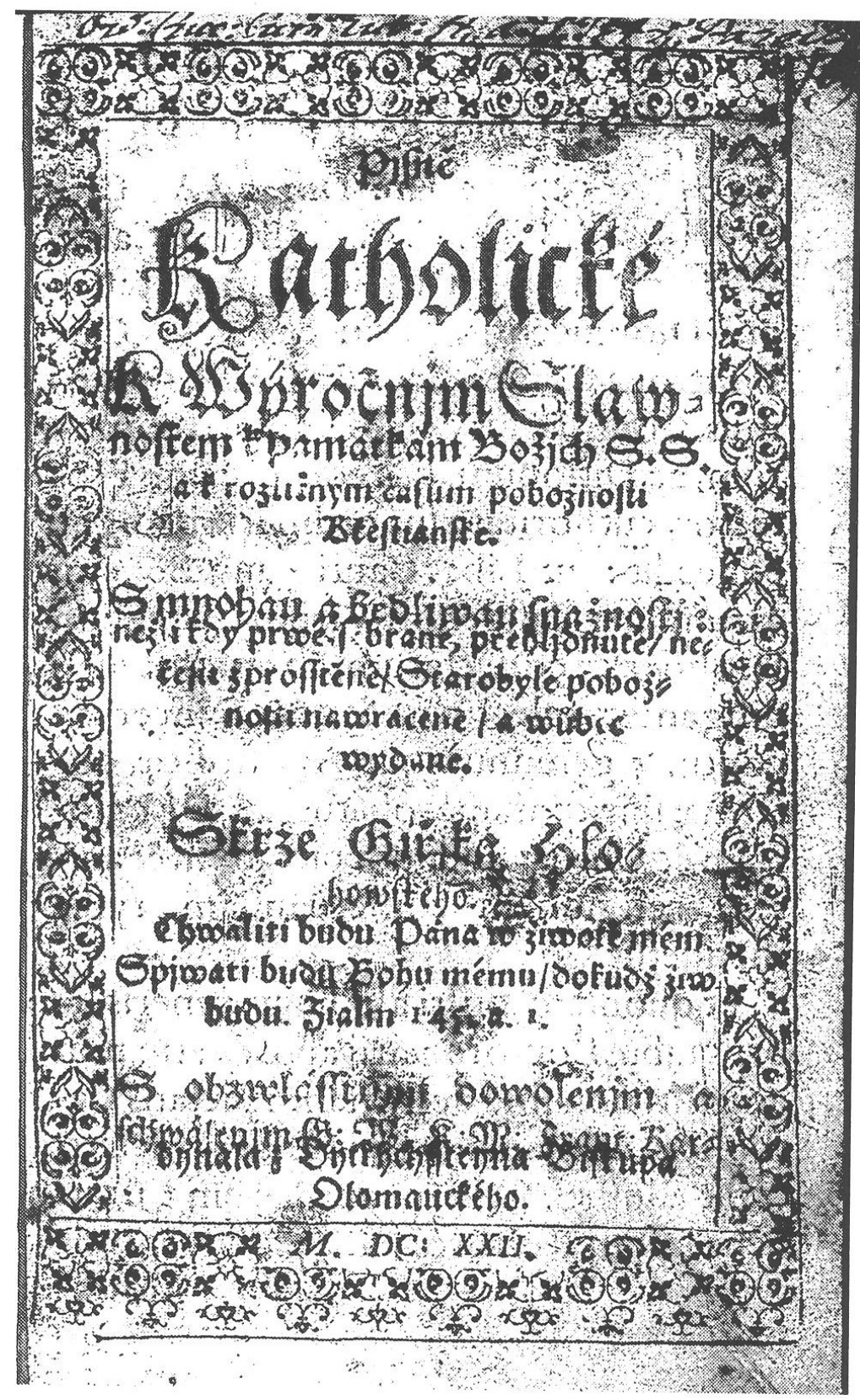

Obrázok 1. Titulný list spevníka Písně katolické (1622)

Figure 1. Title page of the hymn book Písně katolické (1622) 


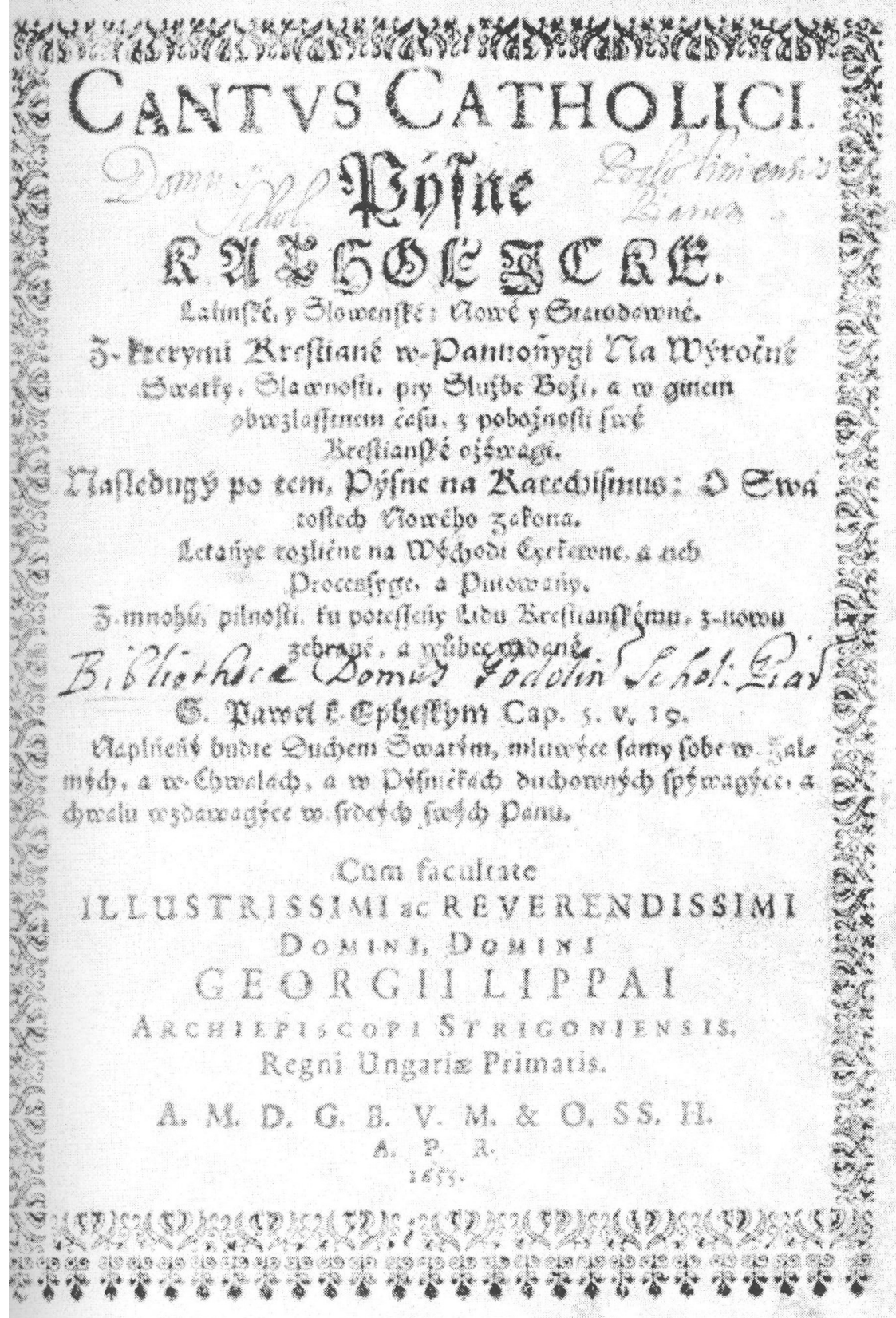

Obrázok 2. Titulný list spevníka Cantus Catholici (1655)

Figure 2 Title page of the hymn book Cantus Catholici (1655) 